\title{
Optimization and evaluation of immediate release pantoprazole sodium sesquihydrate capsule by buffered macro environment method
}

\author{
Preeti Khulbe ${ }^{* 1}$, Deepa Mohan Singh ${ }^{2}$, Neha Riyal $^{3}$, Rohit Kumar ${ }^{4}$ \\ ${ }^{1,2,4}$ Assistant Professor, ${ }^{3}$ Junior safety data analyst \\ 1,2,4 Department of Pharmaceutics, \\ ${ }^{1,2}$ Suresh GyanVihar University, Jagatpura, Jaipur, India \\ ${ }^{3}$ Sciformix Pvt Limited, Pune \\ ${ }^{4}$ Gurunanak College of Pharmacy, Nagpur, Maharashtra \\ Email: khulbe.preeti@yahoo.in ${ }^{1}$,deepamohan.rajput@mygyanvihar.com ${ }^{2}$,nehariyal006@gmail.com ${ }^{3}$, \\ rhtkumar330@gmail.com ${ }^{4}$
}

\begin{abstract}
Pantoprazole sodium inhibits gastric acid secretion through permanent prevention of $(\mathrm{H}+/ \mathrm{K}+)$ ATPase function in gastric parietal cell. In case of immediate relief from ulcer and related gastrointestinal complications it is necessary to release the drug immediately. But, immediate release of proton pump inhibitors such as pentoprozole causes their degradation in gastric medium due to their acid labile nature. Due to this reason pantoprazole is available in the form of enteric coated tablets. The best approach for increasing drug stability in acidic medium is the incorporation of buffer in formulation. Macro-environment buffering method was used in which the whole gastric fluid is buffered by buffering agents. Pantoprazole immediate release granules were prepared by wet granulation method. Sodium starch glycolate and cross carmellose sodium were used as superdisintegarnts. Optimization of the formulation was done by using $2^{3}$ factorial design on formulation P-8. Amount of sodium starch glycolate $(10 \%$ and $12 \%)\left(\mathrm{X}_{1}\right)$, amount of PVPK-30 (3.5\% and 5\%) $\left(\mathrm{X}_{2}\right)$ and amount of mannitol (45\% and 50\%) were used as independent variable. Coded values for 2 levels were -1 and +1 . Ex vivo permeation study was performed in selected optimized batch using non-everted intestinal sac. The results showed $98.86 \%$ release after $30 \mathrm{~min}$. The performance of optimized formulation was compared to the marketed formulation (Pantocid 20mg tablet: Sun Pharmaceutical Industries Ltd.). This article mainly concluded that the macro environmental buffering method can be used for the immediate release of acid labile drug.
\end{abstract}

Index Terms-: Pantoprazole sodium; Proton pump inhibitors; Immediate release; Superdisintegrants; Buffering agents.

\section{INTRODUCTION}

Proton pump inhibitors (PPIs) are antisecretory drugs used to reduce the ulcer and related gastrointestinal (GI) complications ${ }^{[1]}$. PPIs are frequently recommended as the choice of drug in a high-risk patient with gastrointestinal tract (GIT) problems ${ }^{[2]}$. Pantoprazole is one of the best PPI used to treat gastric ulcer. Pantoprazole sodium is a class of PPI that inhibits gastric acid secretion through permanent prevention of $(\mathrm{H}+/ \mathrm{K}+)$-ATPase function in a gastric parietal cell, therefore, decreases the production of gastric acid ${ }^{[3]}$. Pantoprazole is used for temporary treatment of erosive esophagitis related to gastroesophageal reflux disease (GERD), pathophysiological hyperactive secretory conditions with ZollingerEllison Syndrome and maintenance of erosive esophagitis healing ${ }^{[4]}$. The mechanism of action (MOA) of pantoprazole is to prevent the last step in the production of gastric acid. Pantoprazole act through covalently binds to the $\mathrm{H}+/ \mathrm{K}+$ ATP pump to prevent secretion of basal acid and gastric acid in a gastric parietal cell of the stomach. The covalent binding inhibits the secretion of acid up to a one day and night cycle ${ }^{[5]}$.

In case of ulcer and related GI complications for the immediate relief it is necessary to release the drug immediately, but for immediate release pantoprazole, the problem is its stability in the gastric medium ${ }^{[6]}$. As it is known that the pantoprazole is an acid labile drug, so always given as an enteric coated form to protect the drug from the gastric acidic environment ${ }^{[7]}$.So, to make immediate release pantoprazole it is necessary to increase its stability in an acidic environment. The best approach for increasing acid stability is the incorporation of the buffer in the formulation.

The buffered formulations are the formulation containing agents which immediately buffer the internal environment of the body by changing the $\mathrm{pH}$ of the exposed environment, and increases the stability of acid labile drugs inside the body ${ }^{[8]}$. There are two types of buffering methods one is amicroenvironment buffered method and the other one is the macroenvironment buffering method. 


\section{E-ISSN: 2321-9637 \\ Available online at www.ijrat.org}

Here, the second method was used. In this, the whole stomach is buffered by buffering agents.

\section{MATERIALS AND METHODS}

\subsection{Materials}

Pantoprazole sodium sesquihydrate was received as kind gift sample from Akum Drugs (Haridwar, India), Sodium starch glycolate (SSG) was received as kind gift sample from DFE Pharma, Bangalore, India. Croscarmellose sodium (CCS), mannitol and PVPK-30 were purchased from S.D. Fine Chem Ltd., Mumbai, India. Magnesium stearate was purchased from Central Drug House, Delhi, India. Talc was purchased from Loba Chemie Pvt. Ltd, Mumbai, India.

\subsection{Methods}

\subsubsection{Pre-formulation studies}

Pre-formulation studies focus on those physiochemical properties of the compounds that affect the drug performance and development of an efficacious dosage form. A thorough understanding of these properties, ultimately provide a rationale for formulation design. The data outcome of these studies elects many of the succeeding procedures and methods in the development of formulation. Drug identification test and drug excipient compatibility studies were done in this phase to provide a useful support in development of dosage forms. During pre-formulation stage organoleptic properties, melting point determination, micromaretic properties, particle size distribution and powder flow properties were determined using reported methods.

\subsubsection{Compatibility studies}

Compatibility testing was carried out using binary mixture compatibility testing approach. Briefly, the drug and excipients were mixed separately at 1:1 ratio and kept in a clean and dry glass vial. The sample containing glass vial was placed in a stability chamber (TP 200S, Thermolab, Mumbai, India) at $40 \pm 2{ }^{\circ} \mathrm{C}$ and $75 \pm 5 \% \mathrm{RH}$ for a period of 6 months. The samples were analyzed at 0,3 and 6 months as per ICH guidelines ${ }^{[9]}$. The samples were analyzed on the basis of general appearance and IR spectra.

\subsubsection{Solubility analysis}

2.2.3.1 Determination of solubility

The solubility of pure drug was determined using shake flask method by preparing supersaturated solution of drug with water, methanol and ethanol. The samples were analyzed using UVspectrophotometer (UV 3000+, LabIndia, Mumbai, India) at $290 \mathrm{~nm}$ after suitable dilutions ${ }^{[10]}$.

\subsubsection{Determination of partition coefficient}

Partition-coefficient Eq. (1) is the ratio of compound concentrations in a mixture of two immiscible phases at equilibrium. Shake-flask method was used for the determination of partition coefficient. Briefly, $10 \mathrm{mg}$ drug was mixed with 20 $\mathrm{ml}$ of octanol and water in a separating funnel and shaken for about half an hour. The separating funnel was kept for $24 \mathrm{~h}$ and concentration of solute was measured in each solvent using UVspectrophotometer (UV 3000+, Lab India Instruments, Mumbai, India) at $290 \mathrm{~nm}^{[11],[12]}$.

$$
\begin{aligned}
& \text { Partition Coefficient }\left(\mathrm{K}_{\mathrm{o} / \mathrm{w}}\right)= \\
& \frac{\text { Concentration in oil }}{\text { Concentration in water }} \cdot(1)
\end{aligned}
$$

$$
\log \left(\mathrm{P}_{\mathrm{o} / \mathrm{w}}\right)=\log \frac{\text { Concentration in oil }}{\text { Concentration in water }}
$$

\subsubsection{Buffer selection}

Highly acidic gastric environment during fasting conditions creates a physiological barrier for proton pump inhibitors in the stomach due to their acid labile nature. To increase the stability of these drugs in the gastric fluid, there is a need to create a macro-environment. This study was aimed to create macro-environment maintaining gastric $\mathrm{pH}$ in the range of 5 to 6 for improved stability of immediate release pantoprazole. Various soluble and insoluble buffers were tested for their acid neutralizing capacity. The acid neutralizing capacity of individual and combinations buffers were evaluated by providing excess acid according to the need of stomach. ${ }^{[13]}$.

\subsubsection{Determination of $p H$ stability}

In this method, the solution of drug $(20 \mathrm{mg})$ in 50 $\mathrm{ml}$ of different buffer solutions as per IP ( $\mathrm{pH} 1$ to $\mathrm{pH} 7$ ) was prepared. The absorbance was noted down and drug amount was determined with the help of calibration curve after $8 \mathrm{~h}$ in different $\mathrm{pH}$ solutions. The change in color was observed as appearance parameter. The conclusions on $\mathrm{pH}$ dependent stability profile were made based on the amount of drug present in the solution and its physical appearance ${ }^{[13],[14]}$.

\subsubsection{Acid neutralizing capacity (ANC) of different buffers}

In this technique, excess acid was provided according to the need of stomach. The basal fluid of stomach comprises $9.6 \mathrm{ml}$ of $0.1 \mathrm{~N} \mathrm{HCI}$ and releases $0.5 \mathrm{ml}$ of $0.1 \mathrm{~N} \mathrm{HCI}$ per minute. Thus, for making simulated gastric conditions $0.1 \mathrm{~N} \mathrm{HCI}(9.6$ $\mathrm{ml})$ and water $(210 \mathrm{ml})$ and titrated with excess acid $(0.1 \mathrm{HCI})$ at the rate of $0.5 \mathrm{ml} /$ minute for a 60 min. Total volume was maintained at $250 \mathrm{ml}^{[15]}$. 


\section{Available online at www.ijrat.org}

1.2.7. Selection of buffer based on ANC

The buffer combination which maintained the $\mathrm{pH}$ of medium from 5 - 6 for about 30 - 60 min during ANC study was selected for further studies. On the basis of ANC results, combination of calcium lactate and magnesium hydroxide (BF16) was selected.

\subsubsection{Preparation of pantoprazole sodium sesquihydrate IR granules}

Pantoprazole immediate release granules were prepared by wet granulation method ${ }^{[16]}$. All the ingredients, except PVPK 30, talc and magnesium stearate, were weighed, sieved through sieve \# 40 and mixed well. PVP K-30 solution $(2.5,3.5 \& 5 \%$ $\mathrm{w} / \mathrm{v})$ was added as binding agent. The wet mass formed was passed through the sieve \# 10 to form the desired size of granules. The granules were dried in an oven for approximately $1 \mathrm{~h}$ at $60^{\circ} \mathrm{C}$. The dried granules were passed through sieve \# 20. The weighed amount of talc and magnesium stearate was mixed. Finally, the granules were stored in the airtight polybag, and evaluated for micromaretic properties (Table 1).

Table 1: Composition of IR pantoprazole sodium sesquihydrate trial batches.

\begin{tabular}{|c|c|c|c|c|c|c|c|c|}
\hline \multirow{2}{*}{$\begin{array}{l}\text { Ingredie } \\
\text { nts (mg/ } \\
\text { capsule) }\end{array}$} & \multicolumn{8}{|c|}{ Formulation code } \\
\hline & $\mathbf{P}_{1}$ & $\mathbf{P}_{2}$ & $\mathbf{P}_{3}$ & $\mathbf{P}_{4}$ & $\mathbf{P}_{5}$ & $\mathbf{P}_{6}$ & $\mathbf{P}_{7}$ & $\mathbf{P}_{8}$ \\
\hline \multirow{2}{*}{$\begin{array}{l}\text { Pantopra } \\
\text { zole }\end{array}$} & 20 & 20 & 20 & 20 & 20 & 20 & 20 & 20 \\
\hline & .0 & .0 & .0 & .0 & .0 & .0 & .0 & .0 \\
\hline \multirow{2}{*}{$\begin{array}{l}\text { Sodium } \\
\text { starch } \\
\text { glycolate }\end{array}$} & 6. & 10 & 6. & 4. & 8. & 8. & & 8. \\
\hline & 6 & .0 & 0 & 0 & 0 & 0 & - & 0 \\
\hline \multirow{2}{*}{$\begin{array}{l}\text { Croscar } \\
\text { mellose } \\
\text { sodium }\end{array}$} & 4. & 3. & 5. & 10 & 5. & 4. & 8. & \\
\hline & 0 & 0 & 0 & .0 & 0 & 0 & 0 & - \\
\hline \multirow{2}{*}{ Mannitol } & 40 & 38 & 39 & 34 & 36 & 34 & 36 & 36 \\
\hline & .4 & .0 & .2 & .2 & .0 & .0 & .0 & .0 \\
\hline \multirow{2}{*}{$\begin{array}{l}\text { PVPK- } \\
30\end{array}$} & 4. & 4. & 2. & 2. & 2. & 2. & 4. & 4. \\
\hline & 0 & 0 & 8 & 8 & 0 & 0 & 0 & 0 \\
\hline Water & qs & qs & qs & qs & qs & qs & $\mathrm{qs}$ & qs \\
\hline \multirow{2}{*}{ Talc } & 1. & . & 2. & 4. & 4. & 4. & 2. & 2. \\
\hline & 0 & - & 0 & 0 & 0 & 0 & 0 & 0 \\
\hline \multirow{2}{*}{$\begin{array}{l}\text { Magnesi } \\
\text { um } \\
\text { stearate }\end{array}$} & 4. & 5. & 5. & 5. & 5. & 5. & 10 & 10 \\
\hline & 0 & 0 & 0 & 0 & 0 & 0 & .0 & .0 \\
\hline Total & 80 & 80 & 80 & 80 & 80 & 80 & 80 & 80 \\
\hline
\end{tabular}

1.2.9. Optimization of pantoprazole sodium sesquihydrate IR capsules

Based on the results of preliminary trial formulations, full factorial $2^{3}$ design was used on selected formulation (formulation $\mathrm{P}_{8}$ ). Amount of sodium starch glycolate $(10 \%$ and $12 \%)\left(\mathrm{X}_{1}\right)$, amount of PVPK-30 (3.5\% and 5\%) $\left(\mathrm{X}_{2}\right)$ and amount of mannitol (45\% and 50\%) were used as independent variable $\left(\mathrm{X}_{3}\right)$. Coded values for 2 levels were $-1,+1$. Total 8 possible outcomes were prepared. The percentage drug release was selected as the dependent variable ${ }^{[17]}$. The optimization batches were also prepared by same procedure as trial batches (Table 2).

Table 2: Formulations of IR pantoprazole sodium sesquihydrate optimized batch.

\begin{tabular}{|c|c|c|c|c|c|c|c|c|}
\hline \multirow{2}{*}{$\begin{array}{l}\text { Ingredi } \\
\text { ents } \\
\text { (mg/ } \\
\text { capsule) }\end{array}$} & \multicolumn{8}{|c|}{ Formulation code } \\
\hline & $\begin{array}{l}\mathbf{O} \\
\mathbf{P}_{1}\end{array}$ & $\begin{array}{l}\mathbf{O} \\
\mathbf{P}_{2}\end{array}$ & $\begin{array}{l}\mathbf{O} \\
\mathbf{P}_{3}\end{array}$ & $\begin{array}{l}\mathbf{O} \\
\mathbf{P}_{4}\end{array}$ & $\begin{array}{l}\mathbf{O} \\
\mathbf{P}_{5}\end{array}$ & $\begin{array}{l}\mathbf{O} \\
\mathbf{P}_{6}\end{array}$ & $\begin{array}{l}\mathbf{O} \\
\mathbf{P}_{7}\end{array}$ & $\mathrm{OP}_{8}$ \\
\hline $\begin{array}{l}\text { Pantopra } \\
\text { zole }\end{array}$ & $\begin{array}{l}2 \\
0 . \\
0\end{array}$ & $\begin{array}{l}2 \\
0 . \\
0\end{array}$ & $\begin{array}{l}2 \\
0 . \\
0\end{array}$ & $\begin{array}{c}20 \\
.0\end{array}$ & $\begin{array}{c}20 . \\
0\end{array}$ & $\begin{array}{c}20 . \\
0\end{array}$ & $\begin{array}{l}20 \\
.0\end{array}$ & 20.0 \\
\hline $\begin{array}{l}\text { Sodium } \\
\text { starch } \\
\text { glycolat } \\
\mathrm{e}\left(\mathrm{X}_{1}\right)\end{array}$ & $\begin{array}{c}8 . \\
0\end{array}$ & $\begin{array}{c}8 . \\
0\end{array}$ & $\begin{array}{c}8 . \\
0\end{array}$ & $\begin{array}{l}8 . \\
0\end{array}$ & 9.6 & 9.6 & $\begin{array}{c}9 . \\
6\end{array}$ & 9.6 \\
\hline $\begin{array}{l}\text { Mannito } \\
1\end{array}$ & $\begin{array}{l}3 \\
6 . \\
0\end{array}$ & $\begin{array}{l}3 \\
6 . \\
0\end{array}$ & $\begin{array}{l}4 \\
0 . \\
0\end{array}$ & $\begin{array}{r}40 \\
.0\end{array}$ & $\begin{array}{c}36 . \\
0\end{array}$ & $\begin{array}{c}36 . \\
0\end{array}$ & $\begin{array}{r}40 \\
.0\end{array}$ & 40.0 \\
\hline $\begin{array}{l}\text { PVPK- } \\
30\left(\mathrm{X}_{2}\right)\end{array}$ & $\begin{array}{l}4 . \\
0 \\
\end{array}$ & $\begin{array}{l}2 . \\
8\end{array}$ & $\begin{array}{c}4 . \\
0\end{array}$ & $\begin{array}{l}2 . \\
8\end{array}$ & 4.0 & 2.8 & $\begin{array}{l}4 . \\
0\end{array}$ & 2.8 \\
\hline Water & qs & $\begin{array}{c}\text { qs } \\
\text {. }\end{array}$ & $\begin{array}{c}\text { qs } \\
\text {. }\end{array}$ & qs. & qs. & qs. & $\begin{array}{c}\text { qs } \\
\text {. }\end{array}$ & qs. \\
\hline Talc & $\begin{array}{c}2 . \\
0\end{array}$ & $\begin{array}{l}3 . \\
2\end{array}$ & 2 & $\begin{array}{l}2 . \\
0\end{array}$ & 2.0 & 2.0 & $\begin{array}{l}2 . \\
0\end{array}$ & 2.0 \\
\hline $\begin{array}{l}\text { Magnesi } \\
\text { um } \\
\text { stearate }\end{array}$ & $\begin{array}{l}1 \\
0 . \\
0\end{array}$ & $\begin{array}{l}1 \\
0 . \\
0\end{array}$ & $\begin{array}{l}6 . \\
0\end{array}$ & $\begin{array}{l}7 . \\
2\end{array}$ & 8.4 & 9.6 & $\begin{array}{l}4 . \\
4\end{array}$ & 5.6 \\
\hline Total & $\begin{array}{l}8 \\
0\end{array}$ & $\begin{array}{l}8 \\
0\end{array}$ & $\begin{array}{l}8 \\
0\end{array}$ & 80 & 80 & 80 & $\begin{array}{l}8 \\
0\end{array}$ & 80 \\
\hline
\end{tabular}

1.2.10. Evaluation of IR granules

2.2.10.1. Flow properties

Granules ( $5 \mathrm{~g}$ ) were taken into a $10 \mathrm{ml}$ graduated measuring cylinder and the volume was noted down. The measuring cylinder containing sample was tapped 100 times using USP bulk density apparatus (ETD 1020, Electrolab, Mumbai, India). The bulk density and tapped density were determined using the following Eq. $(3,4)$ :

$$
\begin{array}{r}
\text { Bulk density }=\frac{\text { Weight of granules }}{\text { Initial volume }} .(3) \\
\text { Tapped density }=\frac{\text { Weight of granules }}{\text { Final volume after tapping }}
\end{array}
$$

Bulk density and tapped determinations were used to determine the Hausner's ratio using following Eq. (5). : 


\section{Available online at www.ijrat.org}

$$
\text { Hausner's ratio }=\frac{\text { Tapped density }}{\text { Bulk density }} \text {. }
$$

Carr's index was determined using bulk density and tapped density determinations using following Eq. (6). :

$$
\text { Carr's index }=\frac{\text { Tapped density }- \text { Bulk density }}{\text { Tapped density }} \times 100 \text {. }
$$

For the determination of angle of repose, the granules were poured through a funnel fixed at a position such that its lower tip was at a height of 2 $\mathrm{cm}$ above the surface ${ }^{[16]}$. The granules were poured till the tip of granules pile surface touched the funnel. The $\tan ^{-1}$ of ratio the height (h) of the pile and radius ( $r$ ) of its base gave the angle of repose. The angle of repose was determined by following equation:

$$
\tan ^{-1}=\frac{\mathrm{h}}{\mathrm{r}}
$$

\subsubsection{Drug release}

Dissolution profile of the pantoprazole sodium sesquihydrate from IR granules was determined in USP type 1 dissolution test apparatus. The $\mathrm{pH}$ and temperature of dissolution medium was maintained at 5.5 and $37 \pm 0.5^{\circ} \mathrm{C}$, respectively. Dissolution medium $(500 \mathrm{ml})(80 \mathrm{ml} 0.1 \mathrm{~N} \mathrm{HCl}$ mixed with $420 \mathrm{ml}$ water then $(120 \mathrm{mg}$ magnesium hydroxide + $120 \mathrm{mg}$ calcium lactate) buffering agent). A selected size one capsule having $80 \mathrm{mg}$ granules was kept in basket and the basket was rotated at $100 \mathrm{rpm}$. The aliquots were withdrawn at an interval of $10 \mathrm{~min}$ till $30 \mathrm{~min}$ to determine the amount of drug released. Complete sink conditions were maintained by replacing equal volume of the fresh dissolution medium immediately after each sampling.

\subsubsection{Ex vivo permeation study}

Study of ex vivo permeation was carried out by non-everted intestinal sac method ${ }^{[17]}$. Briefly, the Krebs Ringer bicarbonate buffer solution was prepared according to the formula (Table 3). The chicken intestine (small intestine) was procured from a local slaughterhouse. The lumen was cautiously cleaned from mucus by washing with $\mathrm{pH}$ 6.8 Krebs-Ringer solution. Intestinal segment $(6 \mathrm{~cm})$ of was detached and thoroughly washed with oxygenated Krebs-Ringer solution. The intestinal segment was knotted at one end and the sacs were occupied with the $5 \mathrm{ml}$ amount of KerbsRinger bicarbonate buffer solution containing suspension of optimized formulation equivalent to $20 \mathrm{mg}$. The other end of intestinal was ligated carefully. The non-everted sac was submerged in a conical flask containing $100 \mathrm{ml}$ of Kerbs-Ringer bicarbonate buffer. The temperature was maintained at $37 \pm .5^{\circ} \mathrm{C}$. The samples were collected at predetermined time interval. Complete sink condition was maintained by replacing equal volume of fresh Kerbs-Ringer buffer solution immediately after each sampling. Sampling was done 6 times. Analysis of the samples was carried out after suitable dilutions with Kerbs-Ringer buffer solutions using UV Spectrophotometry (UV $3000^{+}$, Lab India, Mumbai, India). The experiment was repeated with marketed formulation for comparative study.

Table 3: Composition of Krebs Ringer bicarbonate solution.

\begin{tabular}{|l|l|}
\hline Composition & $\begin{array}{l}\text { Quantity } \\
(\mathbf{g m} / \mathbf{l})\end{array}$ \\
\hline $\mathrm{NaCl}$ & 7.0 \\
\hline $\mathrm{KCl}$ & 0.06 \\
\hline $\mathrm{CaCl}$ & 0.09 \\
\hline $\mathrm{MgSO}_{4} \cdot 7 \mathrm{H}_{2} \mathrm{O}$ & 0.16 \\
\hline $\mathrm{NaHCO}_{3}$ & 2.3 \\
\hline $\mathrm{KH}_{2} \mathrm{PO}_{4}$ & 0.16 \\
\hline $\mathrm{Glucose}$ & 1.8 \\
\hline
\end{tabular}

\subsubsection{Evaluation of pantoprazole sodium sesquihydrate IR capsules}

Prepared pantoprazole sodium sesquihydrate IR capsules were evaluated based on general appearance, weight variation, disintegration time and dissolution profile. Procedure followed for the dissolution study was same as followed for the IR granules.

\subsubsection{Statistical analysis}

Statistical analysis of the optimization batches (OP1-OP8) was carried out on the bases of full factorial design and response surface plot, two-way ANOVA, and order of reaction. Statistical analysis was carried out using Design Expert 8.0.5.2 software (Stat-Ease, Inc., Minneapolis, Minnesota). The $\mathrm{p}$ value of $<0.05$ was considered statistically significant. To select the optimum formulation, various mathematical models such as zero order and first order were used to describe the kinetics of drug release.

\subsubsection{Comparison of optimized formulation with existing marketed formulation}

A comparison was made between marketed formulation and the optimized formulation CP1 based on drug release pattern (Table 14). As per the search, there was no such formulation available on the market so for pantoprazole IR formulation the comparison was done with marketed enteric coated 


\section{Available online at www.ijrat.org}

pantoprazole tablet (Pantocid $20 \mathrm{mg}$, Sun Pharmaceutical Industries Ltd., Barodara, India).

\subsubsection{Accelerated stability studies of optimized formulation}

Optimized formulation (Formulation CP1) was subjected to accelerated stability testing as per the ICH guidelines. For this, the prepared capsules were placed in a humidity chamber at $40 \pm 2{ }^{\circ} \mathrm{C}$ temp and $75 \pm 5 \%$ RH for 6 months. The samples were tested for stability at 0,3 and 6 months on the bases of general appearance and in vitro drug release.

\section{RESULT AND DISCUSSION}

3.1 Pantoprazole sodium sesquihydrate IR granules

Melting point of the model drug is pantoprazole sodium sesquihydrate was in the range of 141 $144^{\circ} \mathrm{C}$. The particles size was found to be 15 to 195 $\mu \mathrm{m}$. The average bulk density and tapped density of the drug sample was found to be $0.370 \pm 0.042$ $\mathrm{gm} / \mathrm{ml}$ and $0.440 \mathrm{gm} / \mathrm{ml} \pm 0.017$, respectively. The differences in bulk density and tapped density was less, indicating that the change volume is very less even after 100 tapping, which confirms the small particle size range.

The fine particles tend to be more cohesive and therefore less free-flowing, whereas larger denser particles tend to be free-flowing. The particles with rough and irregular surface have higher angle of repose. In the present study, angle of repose of drug was found to be $33.66^{\circ} \pm 0.42$, indicating good flow properties.

A high Carr's index value is indicative of the tendency to form bridges between the particles. Smaller the Carr's index better will be the flow properties. A value of 5-15 indicates excellent, 1218 good, 19-21 fair and 22-35 poor flow, 36-40 very poor and $>40$ extremely poor flow properties of powdered material. In the present study, the Carr's index of the drug was found to be $15.9 \pm$ 1.17 indicating excellent flow characteristics. The observed octanol-water partition coefficient value of pantoprazole sodium sesquihydrate was found to be $2.24 \pm 0.41$.

\subsubsection{Solubility profile}

The solubility of the drug in the different solvent was calculated, and it was found to be very soluble in water because it is BCS class III drug (Table 4).

Table 4: Results of solubility studies of pantoprazole sodium sesquihydrate.

\begin{tabular}{|l|l|}
\hline Water & $\begin{array}{l}\text { Very soluble } \\
(0.463 \mathrm{mg} / \mathrm{ml})\end{array}$ \\
\hline Methanol & $\begin{array}{l}\text { Very soluble } \\
(0.521 \mathrm{mg} / \mathrm{ml})\end{array}$ \\
\hline \multirow{2}{*}{ Ethanol } & $\begin{array}{l}\text { Sparingly } \\
\text { soluble }(4.835 \\
\mathrm{mg} / \mathrm{ml})\end{array}$ \\
\hline
\end{tabular}

\subsubsection{Compatibility studies}

On the basis of general appearance and FTIR study results, it can be concluded that the pantoprazole sodium sesquihydrate was compatible with the selected excepients. There was no change in the general appearance on storage under accelerated environmental conditions. No addition, deletion or shift of peak in IR peak was observed in FTIR spectrum of physical mixture (Figure I).

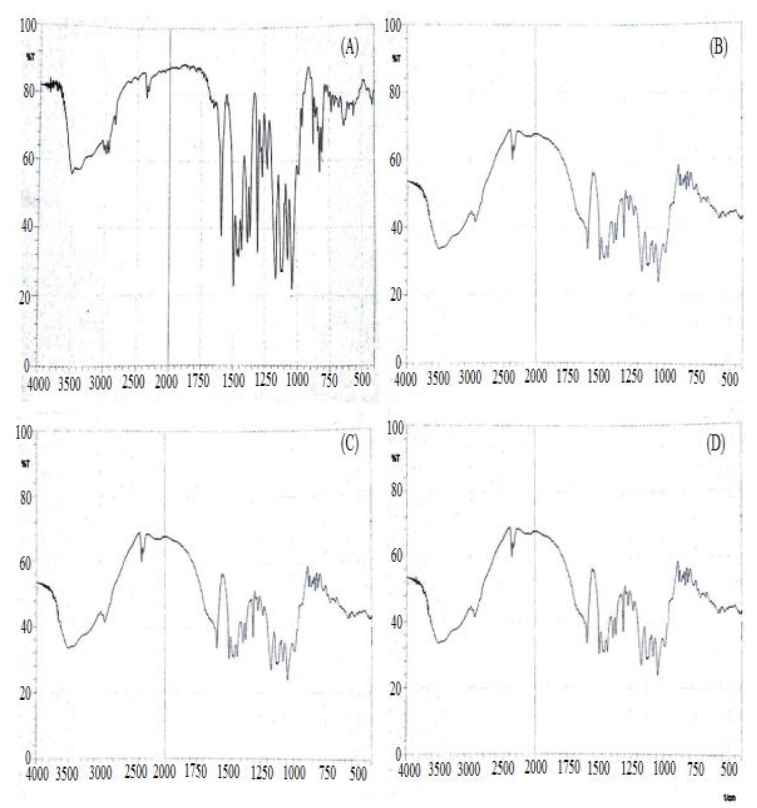

Figure I: FTIR spectrum of pantoprazole sodium sesquihydrate (PN) (A), SSG + PN at zero month (B), SSG + PN after three months (C), SSG + PN) after six months (D).

\subsection{Buffer selection}

3.2.1. $p H$ stability analysis of pantoprazole sodium sesquihydrate

Based on the $\mathrm{pH}$ stability analysis, it can be concluded that the selected drug was unstable in lower $\mathrm{pH}$ (acidic environment). The stability of the drug was increased with an increase in $\mathrm{pH}$ of the medium. The drug was the best stable at $\mathrm{pH}$ 6. The results of $\mathrm{pH}$ stability analysis are shown in Table 5 and Figure II.

Table 5: pH stability analysis of pantoprazole sodium sesquihydrate (PSS).

\begin{tabular}{|l|l|}
\hline Solvent & Solubility \\
\hline
\end{tabular}


Available online at www.ijrat.org

\begin{tabular}{|c|c|c|c|c|c|c|}
\hline $\begin{array}{l}\text { Solu } \\
\text { tion }\end{array}$ & $\begin{array}{l}0.1 \\
N \\
\mathrm{HC} \\
\text { l }\end{array}$ & $\begin{array}{l}\mathrm{HC} \\
\text { l } \\
\text { Buf } \\
\text { fer }\end{array}$ & $\begin{array}{l}\text { HC } \\
\text { l } \\
\text { Buf } \\
\text { fer }\end{array}$ & $\begin{array}{l}\text { Buff } \\
\text { ered } \\
\text { SGF }\end{array}$ & $\begin{array}{l}\text { Phosp } \\
\text { hate } \\
\text { Buffe } \\
\text { r }\end{array}$ & $\begin{array}{l}\text { Phosp } \\
\text { hate } \\
\text { Buffe } \\
\text { r }\end{array}$ \\
\hline $\mathrm{pH}$ & $\begin{array}{l}\mathrm{pH} \\
1.3\end{array}$ & $\begin{array}{l}\mathrm{pH} \\
2\end{array}$ & $\begin{array}{l}\mathrm{pH} \\
3\end{array}$ & $\mathrm{pH} 5$ & pH 6 & pH 7.2 \\
\hline $\begin{array}{l}\text { Cha } \\
\text { nge } \\
\text { in } \\
\text { colo } \\
\text { ur } \\
\text { ur }\end{array}$ & $\begin{array}{l}\text { Bro } \\
\text { wn } \\
\text { col } \\
\text { our }\end{array}$ & $\begin{array}{l}\text { Dar } \\
k \\
\text { yell } \\
\text { ow }\end{array}$ & $\begin{array}{l}\text { Lig } \\
\text { ht } \\
\text { yell } \\
\text { ow }\end{array}$ & $\begin{array}{l}\text { Clea } \\
\text { r } \\
\text { whit } \\
\text { e }\end{array}$ & $\begin{array}{l}\text { Light } \\
\text { precip } \\
\text { itated } \\
\text { soluti } \\
\text { on } \\
\end{array}$ & $\begin{array}{l}\text { Precip } \\
\text { itated } \\
\text { white }\end{array}$ \\
\hline $\begin{array}{l}\text { PSS } \\
\text { (mg/ } \\
\mathrm{ml}) \\
\text { after } \\
8 \mathrm{~h}\end{array}$ & $\begin{array}{l}0.2 \\
91\end{array}$ & $\begin{array}{l}2.9 \\
8\end{array}$ & $\begin{array}{l}4.2 \\
3\end{array}$ & $\begin{array}{l}12.2 \\
7\end{array}$ & 14.09 & 13.52 \\
\hline
\end{tabular}

\begin{tabular}{|l|l|c|c|}
\hline & Oxide & & \\
\hline BF-6 & $\begin{array}{l}\text { Calcium } \\
\text { lactate }\end{array}$ & 150 & 5.8 \\
\hline
\end{tabular}

Table 7: Acid neutralizing capacity of buffer (using combination of chemicals).

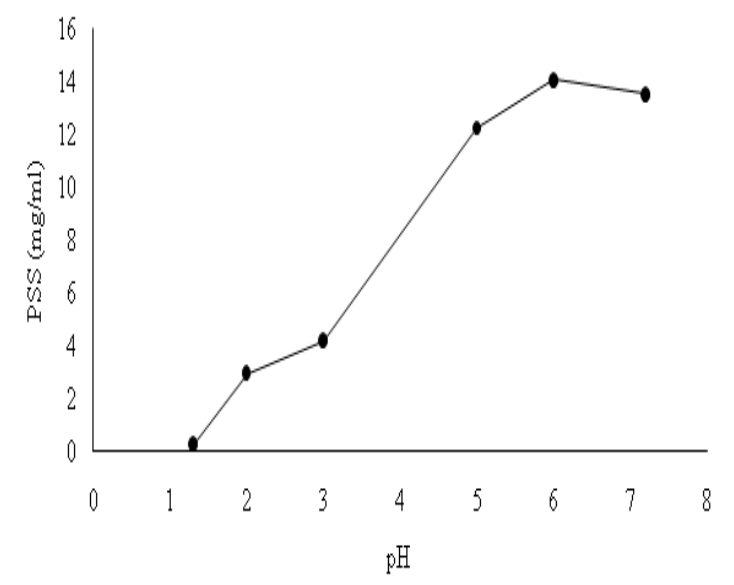

Figure II: Results of pH stability study of pantoprazole sodium sesquihydrate.

\subsubsection{Acid neutralizing capacity (ANC) of different buffers}

On the basis of observation, it can be concluded that the best combination of buffers for acid neutralization of SGF was calcium lactate and magnesium hydroxide (BF 16) (Table 6 and 7).

Table 6: Results of acid neutralizing capacity of buffer (using single chemical), BF: Buffer.

\begin{tabular}{|c|l|c|c|}
\hline $\begin{array}{c}\text { Serial } \\
\text { No. }\end{array}$ & $\begin{array}{l}\text { Selected } \\
\text { ingredients }\end{array}$ & $\begin{array}{c}\text { Quantity } \\
\text { (mg) }\end{array}$ & $\begin{array}{c}\text { Observed } \\
\text { pH }\end{array}$ \\
\hline BF-1 & $\begin{array}{l}\text { Sodium } \\
\text { Bicarbonate }\end{array}$ & 100 & 9.2 \\
\hline BF-2 & $\begin{array}{l}\text { Sodium } \\
\text { Carbonate }\end{array}$ & 200 & 8.5 \\
\hline BF-3 & $\begin{array}{l}\text { Magnesium } \\
\text { Hydroxide }\end{array}$ & 50 & 5.3 \\
\hline BF-4 & $\begin{array}{l}\text { Calcium } \\
\text { Carbonate }\end{array}$ & 300 & 7.7 \\
\hline BF-5 & Magnesium & 100 & 7.4 \\
\hline
\end{tabular}

\begin{tabular}{|c|c|c|c|c|c|c|c|}
\hline \multirow[b]{2}{*}{$\begin{array}{l}\text { Sl } \\
\dot{\text { N }} \\
\text { o. }\end{array}$} & \multirow[b]{2}{*}{$\begin{array}{l}\text { Selected } \\
\text { Ingredients }\end{array}$} & \multirow[b]{2}{*}{\begin{tabular}{|l} 
Qu \\
anti \\
ty \\
Use \\
d \\
$(\mathbf{m g})$
\end{tabular}} & \multicolumn{5}{|c|}{ pH } \\
\hline & & & $\begin{array}{c}\text { Obse } \\
\text { rved }\end{array}$ & $\begin{array}{l}\text { afte } \\
\text { r } 15 \\
\text { min } \\
*\end{array}$ & $\begin{array}{l}\text { afte } \\
\mathbf{r} \\
\mathbf{3 0} \\
\text { min } \\
*\end{array}$ & $\begin{array}{l}\text { afte } \\
\mathbf{r} \\
45 \\
\min \\
*\end{array}$ & $\begin{array}{l}\text { afte } \\
\mathbf{r} \\
\mathbf{6 0} \\
\text { min } \\
*\end{array}$ \\
\hline $\begin{array}{l}\text { B } \\
\text { F- } \\
7\end{array}$ & $\begin{array}{l}\text { Sodium } \\
\text { bicarbonate: } \\
\text { magnesium } \\
\text { hydroxide }\end{array}$ & $\begin{array}{l}50: \\
50\end{array}$ & 5.8 & $\begin{array}{l}1 . \\
9\end{array}$ & $\begin{array}{l}\mathrm{N} \\
\mathrm{A}\end{array}$ & $\begin{array}{l}\mathrm{N} \\
\mathrm{A}\end{array}$ & $\begin{array}{l}\mathrm{N} \\
\mathrm{A}\end{array}$ \\
\hline $\begin{array}{l}\text { B } \\
\text { F- } \\
8\end{array}$ & $\begin{array}{l}\text { Sodium } \\
\text { Bicarbonate } \\
: \\
\text { magnesium } \\
\text { hydroxide }\end{array}$ & $\begin{array}{l}100 \\
: 50\end{array}$ & 6.7 & $\begin{array}{l}3 . \\
2\end{array}$ & $\begin{array}{l}\mathrm{N} \\
\mathrm{A}\end{array}$ & $\begin{array}{l}\mathrm{N} \\
\mathrm{A}\end{array}$ & $\begin{array}{l}\mathrm{N} \\
\mathrm{A}\end{array}$ \\
\hline $\begin{array}{l}\text { B } \\
\text { F- } \\
9\end{array}$ & $\begin{array}{l}\text { Sodium } \\
\text { bicarbonate: } \\
\text { magnesium } \\
\text { hydroxide }\end{array}$ & $\begin{array}{l}100 \\
: 10 \\
0\end{array}$ & 7 & $\begin{array}{l}3 . \\
8\end{array}$ & $\begin{array}{l}2 . \\
6\end{array}$ & $\begin{array}{l}\mathrm{N} \\
\mathrm{A}\end{array}$ & $\begin{array}{l}\mathrm{N} \\
\mathrm{A}\end{array}$ \\
\hline $\begin{array}{l}\text { B } \\
\text { F- } \\
10\end{array}$ & $\begin{array}{l}\text { Sodium } \\
\text { bicarbonate: } \\
\text { magnesium } \\
\text { hydroxide }\end{array}$ & $\begin{array}{l}250 \\
: \\
250\end{array}$ & 8.7 & $\begin{array}{l}\mathrm{N} \\
\mathrm{A}\end{array}$ & $\begin{array}{l}\mathrm{N} \\
\mathrm{A}\end{array}$ & $\begin{array}{l}\mathrm{N} \\
\mathrm{A}\end{array}$ & $\begin{array}{l}\mathrm{N} \\
\mathrm{A}\end{array}$ \\
\hline $\begin{array}{l}\text { B } \\
\text { F- } \\
11\end{array}$ & $\begin{array}{l}\text { Sodium } \\
\text { Bicarbonate } \\
: \text { calcium } \\
\text { carbonate }\end{array}$ & $\begin{array}{l}50: \\
50\end{array}$ & 6.3 & $\begin{array}{l}2 . \\
7\end{array}$ & $\begin{array}{l}1 . \\
6\end{array}$ & $\begin{array}{l}\mathrm{N} \\
\mathrm{A}\end{array}$ & $\begin{array}{l}\mathrm{N} \\
\mathrm{A}\end{array}$ \\
\hline $\begin{array}{l}\text { B } \\
\text { F- } \\
12\end{array}$ & $\begin{array}{l}\text { Sodium } \\
\text { bicarbonate: } \\
\text { calcium } \\
\text { carbonate }\end{array}$ & $\begin{array}{l}100 \\
: \\
100\end{array}$ & 8.1 & $\begin{array}{l}6 . \\
6\end{array}$ & $\begin{array}{l}5 . \\
9\end{array}$ & 4 & $\begin{array}{l}2 . \\
1\end{array}$ \\
\hline $\begin{array}{l}\text { B } \\
\text { F- } \\
13 \\
\end{array}$ & $\begin{array}{l}\text { Calcium } \\
\text { carbonate: } \\
\text { magnesium } \\
\text { hydroxide }\end{array}$ & $\begin{array}{l}100 \\
: \\
100\end{array}$ & 6 & $\begin{array}{l}5 . \\
8\end{array}$ & $\begin{array}{l}5 . \\
1\end{array}$ & $\begin{array}{l}4 . \\
3\end{array}$ & $\begin{array}{l}3 . \\
8\end{array}$ \\
\hline $\begin{array}{l}\text { B } \\
\text { F- } \\
14\end{array}$ & $\begin{array}{l}\text { Calcium } \\
\text { carbonate: } \\
\text { magnesium } \\
\text { hydroxide }\end{array}$ & $\begin{array}{l}120 \\
: \\
120\end{array}$ & 6.8 & 6 & $\begin{array}{l}5 . \\
5\end{array}$ & 5 & $\begin{array}{l}4 . \\
2\end{array}$ \\
\hline $\begin{array}{l}\text { B } \\
\text { F- } \\
15\end{array}$ & $\begin{array}{l}\text { Calcium } \\
\text { lactate: } \\
\text { magnesium } \\
\text { hydroxide } \\
\end{array}$ & $\begin{array}{l}100 \\
: \\
100\end{array}$ & 6.5 & $\begin{array}{l}4 . \\
7\end{array}$ & $\begin{array}{l}3 . \\
6\end{array}$ & $\begin{array}{l}\mathrm{N} \\
\mathrm{A}\end{array}$ & $\begin{array}{l}\mathrm{N} \\
\mathrm{A}\end{array}$ \\
\hline $\begin{array}{l}\text { B } \\
\text { F- } \\
16\end{array}$ & $\begin{array}{l}\text { Calcium } \\
\text { lactate: } \\
\text { magnesium } \\
\text { hydroxide }\end{array}$ & $\begin{array}{l}120 \\
: \\
120\end{array}$ & 6.5 & $\begin{array}{l}5 . \\
6\end{array}$ & $\begin{array}{l}5 . \\
4\end{array}$ & $\begin{array}{l}5 . \\
2\end{array}$ & 5 \\
\hline
\end{tabular}




\section{Available online at www.ijrat.org}

\#BF: Buffer, NA: Not Applicable, *addition of $0.1 \mathrm{~N}$ $\mathrm{HCl}$ according to $0.5 \mathrm{ml} / \mathrm{min}$ rate.

The advantage of using calcium lactate is it is also used as calcium supplement. If this buffer accumulates into the body it may not cause any harm and it will be beneficial ${ }^{(16)}$.

\subsection{Micromeretic properties of IR granules of pantoprazole sodium sesquihydrate}

The prepared IR granules of pantoprazole sodium sesquihydrate trial bathes had angle of repose $36 \pm$ $1^{\circ}$ and compressibility index $17 \pm 1 \%$ indicating fair to good flow properties. In case of optimized batches granules, on the bases observations the average bulk density of the given drug was found to be $0.370 \mathrm{gm} / \mathrm{ml}$. The observed average tapped density of the given drug was found to be 0.440 $\mathrm{gm} / \mathrm{ml}$. The angle of repose was found to be $35^{\circ}$ $36^{\circ}$ and the compressibility index was from 16 $17 \%$ indicating good flow properties.

\subsection{Drug release from IR granules}

The drug release from IR granules and optimized IR granules were determined (Figure III and IV).

\section{Cumulative \% drug release of PPS immediate release granules}

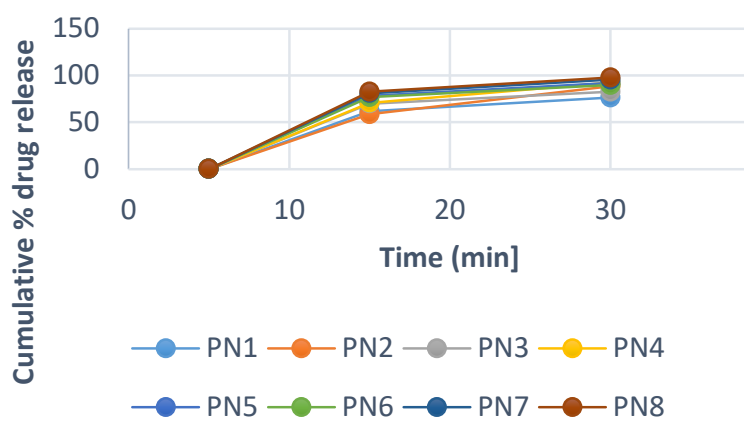

Figure III: \% Cumulative drug release of pantoprazole sodium sesquihydrate IR granules (Trial batch).

Discussion: For making immediate release PSS two superdisintegrants SSG and CCS were selected. PVPK 30 was used as binder for wet granulation and mannitol was used as diluent in the formulation. Magnesium stearate and talc were selected as lubricants. As per the table 7.24 the drug release from P1 after $30 \mathrm{~min}$ was only $76.42 \%$. To improve the release formulations P2 to P8 were designed with different ratio of superdisintegrants.

At last formulation P7 was designed by using single disintegrant CCS and the amount of PVPK
30 was adjusted. In P8 the formula remains same only the superdisintegrant SSG was used instead of CCS. The release after $15 \mathrm{~min}$ was 80.95 and 82.49 and after 30 min was 95.48 and 97.64 from P7 and $\mathrm{P} 8$ respectively.

From above results it can be concluded that SSG is better superdisintegrant then CCS. The amount of PVPK 30 responsible for the initial release of drug from the formulation.

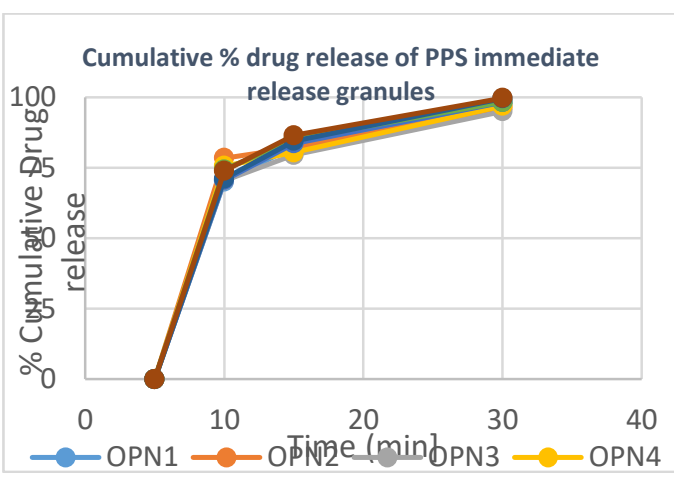

Figure IV: Percentage Cumulative drug release of pantoprazole sodium sesquihydrate IR granules (Optimization batch).

Discussion: From all the initially prepared eight (P1-P8) trial batch formulations P8 was selected for further optimization. Again eight formulations were prepared by using different concentrations of SSG, PVPK30 and mannitol. In formulation OP1 to OP8 it was observed that as the concentration of PVPK30 was decreased the initial release of the formulation was increased whereas as the concentration of SSG was increased the release of the drug was increased. formulation OP7 and OP8 released maximum amount (99.61 \& 99.72 respectively) of drug after $30 \mathrm{~min}$. but in case of OP7 the initial amount of drug after $15 \mathrm{~min}$ is slightly low (84.48) as compare to OP8 (86.54) because of the percentage of PVPK 30 . So OP8 was selected as the best formulation and used for the further study.

\subsection{Ex vivo permeation study}

The results of ex vivo permeation study suggested that the optimized formulation (formulation OP8) showed better release profile when compared to the marketed formulation (Pantocid $20 \mathrm{mg}$, Sun Pharmaceutical Industries Ltd., Barodara, India). The results of ex vivo permeation study are shown in Figure VI. 


\section{Available online at www.ijrat.org}

\section{PERCENTAGE CUMULATIVE DRUG PERMEATED}

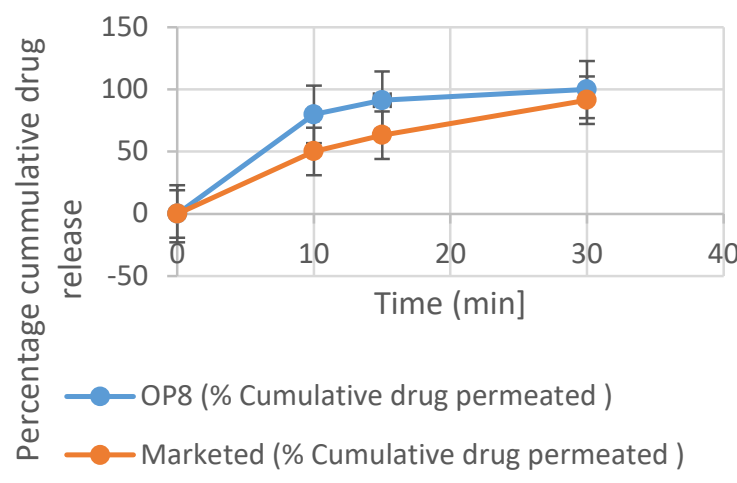

Figure VI: Comparative ex-vivo permeation results of marketed and optimized pantoprazole sodium sesquihydrate formulation.

\subsection{Statistical analysis of optimized pantoprazole sodium sesquihydrate IR formulation}

On the bases of statistical results, it can be concluded that SSG and PVPK-30 has a significant effect on drug release. Mannitol did not have significant $(\mathrm{p}<0.05)$ effect on drug release (Table $8)$. Response surface plots suggest that the elevated level of PVP K-30 has negative effect on drug release. Whereas SSG showed the high value of percentage drug release at its elevated level indicating significant $(\mathrm{p}<0.05)$ effect on drug release as the calculate $\mathrm{F}$ value was higher.

Table 8: Analysis of variance (ANOVA) of immediate release pantoprazole sodium sesquihydrate for dependent variables from factorial design using SPC.

\begin{tabular}{|l|l|l|l|l|}
\hline Factors & $\begin{array}{l}\text { Sum } \\
\text { of } \\
\text { squar } \\
\text { e }\end{array}$ & $\begin{array}{l}\text { Degree } \\
\text { of } \\
\text { freedo } \\
\text { m }\end{array}$ & $\begin{array}{l}\text { Mean } \\
\text { Squar } \\
\text { e }\end{array}$ & $\begin{array}{l}\text { Calculate } \\
\text { d F }\end{array}$ \\
\hline SSG & 9.844 & 1 & 9.844 & 119.239 \\
\hline $\begin{array}{l}\text { Mannito } \\
1\end{array}$ & 0.501 & 1 & 0.501 & 6.063 \\
\hline $\begin{array}{l}\text { PVP K- } \\
30\end{array}$ & 0.363 & 1 & 0.363 & 4.397 \\
\hline \multicolumn{4}{|l|}{ Polynomial y $=0.0822 \mathrm{x}^{2}+4.571 \mathrm{x}+36.47$} \\
\hline
\end{tabular}
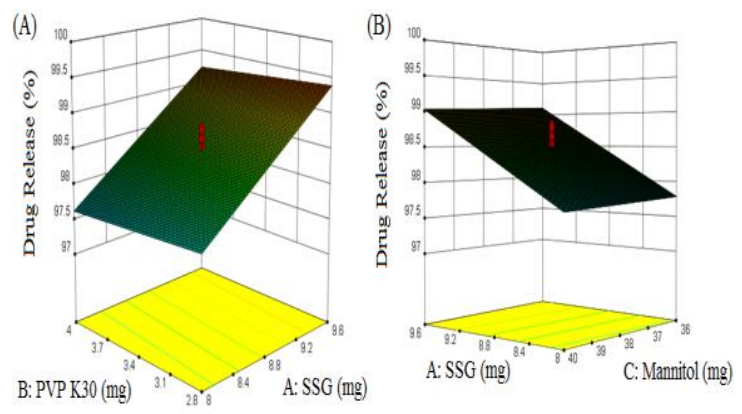

Figure VII: Response surface plots showing the effect of PVP K 30 and SSG on drug release of pantoprazole sodium sesquihydrate (A), and effect of mannitol and SSG on drug release of pantoprazole sodium sesquihydrate (B).

As per the results of mathematical model shown in Table 9, it can be concluded that the drug release profile of pantoprazole sodium sesquihydrate immediate release formulation followed first order release.

Table 9: Mathematical model of drug release profile immediate release pantoprazole sodium sesquihydrate.

\begin{tabular}{|c|c|c|}
\hline \multirow{2}{*}{$\begin{array}{l}\text { Formulation } \\
\text { code }\end{array}$} & \multicolumn{2}{|c|}{ Regression values } \\
\hline & $\begin{array}{l}\text { Zero } \\
\text { order } \\
\left(\mathbf{R}^{2}\right)\end{array}$ & $\begin{array}{l}\text { First } \\
\text { order } \\
\left(\mathbf{R}^{2}\right)\end{array}$ \\
\hline OP1 & 0.9512 & 0.9212 \\
\hline OP2 & 0.8809 & 0.8986 \\
\hline OP3 & 0.9696 & 0.9532 \\
\hline OP4 & 0.9318 & 0.9681 \\
\hline OP5 & 0.9369 & 0.9432 \\
\hline OP6 & 0.9429 & 0.9633 \\
\hline$\overline{\text { OP7 }}$ & 0.9292 & 0.9583 \\
\hline$\overline{\text { OP8 }}$ & 0.9301 & 0.9780 \\
\hline
\end{tabular}

\subsection{Evaluation of optimized immediate release} capsules

Optimized $80 \mathrm{mg}$ IR granules contains $20 \mathrm{mg}$ drug were filled along with buffering agent (BF 16) in size one hard gelatine capsule (CP1). The prepared capsule showed almost same release rate as the optimized granules. So CP1 was the final formulation which was then compared with the marketed formulation (Table 10).

Table 10: Results of evaluation of optimized IR capsules.

\begin{tabular}{|c|c|c|c|c|}
\hline $\begin{array}{c}\text { Gene } \\
\text { ral }\end{array}$ & $\begin{array}{c}\text { Av } \\
\text { g. }\end{array}$ & $\begin{array}{c}\text { Wei } \\
\text { ght }\end{array}$ & $\begin{array}{c}\text { Disint } \\
\text { egrati }\end{array}$ & $\begin{array}{c}\text { Cumula } \\
\text { tive } \\
\text { appea }\end{array}$ \\
W & vari & on & drug \\
\hline
\end{tabular}




\section{Available online at www.ijrat.org}

\begin{tabular}{|c|c|c|c|c|}
\hline rance & $\begin{array}{l}\text { t. } \\
(\mathbf{m} \\
\mathrm{g})\end{array}$ & $\begin{array}{c}\text { atio } \\
\mathbf{n} \\
(\mathbf{m g}\end{array}$ & $\begin{array}{c}\text { time } \\
(\mathrm{min})\end{array}$ & $\begin{array}{c}\text { released } \\
(\%) 30 \\
\text { min }\end{array}$ \\
\hline $\begin{array}{l}\text { Yello } \\
\text { w cap } \\
\text { and } \\
\text { body }\end{array}$ & $\begin{array}{c}17 \\
2.1 \\
5\end{array}$ & $\begin{array}{l}170 \\
\pm 3 \\
35\end{array}$ & $10 \pm 2$ & 98.86 \\
\hline
\end{tabular}

3.8 Comparison of optimized formulation with existing marketed formulation

Based on observation, it can be concluded that in prepared optimized formulation the release of pantoprazole was fast and immediate as compared to the selected marketed formulation (Table 11).

Table 11: Comparison of optimized formulation with existing marketed formulation.

\begin{tabular}{|l|l|l|}
\hline $\begin{array}{l}\text { Formulat } \\
\text { ion }\end{array}$ & $\begin{array}{l}\text { Cumulati } \\
\text { ve drug } \\
\text { released } \\
(\%) \text { 30 } \\
\text { min }\end{array}$ & $\begin{array}{l}\text { Cumulati } \\
\text { ve drug } \\
\text { released } \\
(\%) \text { 30 } \\
\text { min }\end{array}$ \\
\hline $\begin{array}{l}\text { Marketed } \\
\text { formulatio } \\
\text { n }\end{array}$ & 0 & 0 \\
\hline $\begin{array}{l}\text { Formulati } \\
\text { on CP1 }\end{array}$ & 82.04 & 98.8 \\
\hline
\end{tabular}

3.3.1 Accelerated Stability Studies (ICH: $40 \pm 2{ }^{\circ} \mathrm{C}$ Temp. \& $75 \pm 5 \%$ RH) of optimized formulation

As per the observations, it can be concluded that the optimized formulation (CP1) as there was no changes were observed in general appearance as well as in drug release when exposed to accelerated environmental conditions (Table 12).

Table 12: Accelerated Stability Studies of Optimized Formulation (CP1).

\begin{tabular}{|l|l|l|l|}
\hline Time & $\begin{array}{l}\text { General } \\
\text { appearan } \\
\text { ce }\end{array}$ & $\begin{array}{l}\text { Cumulati } \\
\text { ve drug } \\
\text { released } \\
(\boldsymbol{\%}) \mathbf{1 5} \\
\text { min }\end{array}$ & $\begin{array}{l}\text { Cumulati } \\
\text { ve drug } \\
\text { released } \\
(\boldsymbol{\%}) \mathbf{3 0} \\
\text { min }\end{array}$ \\
\hline $\begin{array}{l}\text { Zero } \\
\text { Mont } \\
\text { h }\end{array}$ & $\begin{array}{l}\text { Yellow } \\
\text { Cap and } \\
\text { Body }\end{array}$ & 82.04 & 98.86 \\
\hline $\begin{array}{l}\text { Three } \\
\text { Mont } \\
\text { h }\end{array}$ & $\begin{array}{l}\text { Yellow } \\
\text { Cap and } \\
\text { Body }\end{array}$ & 81.13 & 98.32 \\
\hline Six & Yellow & 82.54 & 98.41 \\
\hline
\end{tabular}

\begin{tabular}{|l|l|l|l|}
\hline $\begin{array}{l}\text { Mont } \\
\text { h }\end{array}$ & $\begin{array}{l}\text { Cap and } \\
\text { Body }\end{array}$ & & \\
\hline
\end{tabular}

\section{CONCLUSION}

From above study it can be concluded that for the prevention of acid labile drug from degradation or making the immediate release formulation of acid labile drug buffer can be used. Microenvironment method of buffering was found to be the easiest method to enhance the drug stability. On the basis of observations, it can also have concluded that the formulation showed immediate release of stable pantoprazole sodium sesquihydrate due to the presence of in-situ buffering agents inside the capsule. Further work can be done to reduce the size of the formulation and to improve the release pattern by using novel technology.

\section{Conflict of interest}

No conflict of interest between authors

\section{Acknowledgement}

I thank all my seniors and friends for the support during this research.

\section{REFERENCES}

[1] 1. Scheiman JM. (2013) The use of proton pump inhibitors in treating and preventing NSAID-induced mucosal damage. Arthritis Research \& Therapy,15(Suppl 3), pp:S5-S.

[2] 2. Gutermann IK, Niggemeier V, Zimmerli LU, Holzer BM, Battegay E, Scharl M. (2015) Gastrointestinal Bleeding and Anticoagulant or Antiplatelet Drugs: Systematic Search for Clinical Practice Guidelines. Medicine, 94(1), pp:e377.

[3] 3. Shin JM, Kim N. (2013) Pharmacokinetics and Pharmacodynamics of the Proton Pump Inhibitors. Journal of Neurogastroenterology and Motility,19(1), pp:25-35.

[4] 4. Scholten T. (2007) Long-term management of gastroesophageal reflux disease with pantoprazole. Therapeutics and Clinical Risk Management,3(2), pp:231-43.

[5] 5. Shin JM, Sachs G. (2008) Pharmacology of Proton Pump Inhibitors. Current gastroenterology reports, 10(6) , pp:528-34.

[6] 6. Maradey-Romero C, Fass R. (2014) New and Future Drug Development for Gastroesophageal Reflux Disease. Journal of Neurogastroenterology and Motility, 20(1), pp:6-16.

[7] 7. Tirpude RN, Puranik PK. (2011) Rabeprazole sodium delayed-release multiparticulates: Effect of enteric coating layers on product performance. Journal of Advanced Pharmaceutical Technology \& Research,2(3), pp.184-91. 


\section{Available online at www.ijrat.org}

[8] 8. Joguparthi V, Feng S, Anderson BD.(2008) Determination of Intraliposomal pH and its Effect on Membrane Partitioning and Passive Loading of a Hydrophobic Camptothecin, DB-67. International journal of pharmaceutics,352(1-2), pp.17-28.

[9] 9. Kumar A, Nanda S, Chomwal R. (2010) Spectrophotometric estimation of betahistine hydrochloride in tablet formulations. Journal of Pharmacy and Bioallied Sciences, 2(2), pp.121-3.

[10] 10. Graffner C, Johansson ME, Nicklasson M, Nyqvist H. (1985) Preformulation studies in a drug development program for tablet formulations. Journal of pharmaceutical sciences,74(1) pp. 16-20.

[11]11. Thumma S, Majumdar S, ElSohly MA, Gul W, Repka MA. (2008) Preformulation Studies of a Prodrug of $\Delta(9)$ Tetrahydrocannabinol. AAPS PharmSciTech,9(3), pp.982-90.

[12] 12. Migoha CO, Ratansi M, Kaale E, Kagashe G. (2015) Preformulation Studies for Generic Omeprazole Magnesium Enteric Coated Tablets. BioMed Research International, pp.307032.

[13]13. Aslani A, Sharifian T. (2014) Formulation, characterization and physicochemical evaluation of amoxicillin effervescent tablets. Advanced Biomedical Research,3, pp.209.

[14] 14. Bak A, Leung D, Barrett SE, Forster S, Minnihan EC, Leithead AW, et al. (2015) Physicochemical and Formulation Developability Assessment for Therapeutic Peptide Delivery-A Primer. The AAPS Journal,17(1), pp.144-55.

[15] 15. Lin MS, Sun P, Yu HY. (1998) Evaluation of buffering capacity and acid neutralizing-pH time profile of antacids. Journal of the Formosan Medical Association = Taiwan yi zhi., 97(10),pp.704-10.

[16] 16. Lacaze C, Kauss T, Kiechel J-R, Caminiti A, Fawaz F, Terrassin L, et al. (2011)The initial pharmaceutical development of an artesunate/amodiaquine oral formulation for the treatment of malaria: a public-private partnership. Malaria Journal, 10, pp.142-145.

[17] 17. Jishnu V, Prabhakaran R, Gilhotra RM.(2011) Formulation and Evaluation of Cephalexin Extended Release Matrix Tablets Using 3(2) Factorial Design. Journal of Young Pharmacists : JYP,3(4),pp.259-66. 